\title{
Submarine terraces reveal Late Quaternary tectonic deformation in the intermediate zone between the island shelf and rift zone of the middle part of the Nanseishoto Islands, southwest Japan
}

\author{
Hideaki Goto* ${ }^{*}$
}

\begin{abstract}
Late Quaternary tectonic deformation of coastal areas is usually examined based on the height distribution of paleoshorelines observed on marine terraces. However, it is difficult to examine deformation along the subduction zone, in which small, isolated islands are distributed. In this paper, the author focuses on the widespread shallow submarine terraces surrounding the Iheya-Izena islands in the middle part of the Nanseishoto Islands, Southwest Japan, where crustal deformation is not known. The islands are located in the intermediate zone between island shelf uplifted during the Late Quaternary and the rift zone occurred to the northwest, along the Okinawa trough. Detailed topographic anaglyph images and maps of the islands were produced using a digital elevation model (DEM) of the seafloor, which is stored by the Japan Coast Guard (JCG) and the Advanced Institute of Science and Technology (AIST). Topographic anaglyph images enabled us to identify the widespread distribution and deformation of the shallow seafloor above - $200 \mathrm{~m}$ using red-cyan glasses. Four terrace-like features divided by small steps were found on the shallow seafloor, which are named T1, T2, T3, and T4, in descending order. Topographic expressions of paleo-shoreline depths are preserved on submarine terraces formed during the last glacial period. The paleo-shoreline depths of terraces T2 and T3 are $-60 \mathrm{~m}$ and $-70 \mathrm{~m}$ on the west side and $-70 \mathrm{~m}$ and $-80 \mathrm{~m}$, respectively, on the east side of Iheyajima Island; this indicates southeastward tilting. The tilting ratio of $\mathrm{T} 2$ and $\mathrm{T} 3$ was calculated to approximately $1 \%$. The tilting rate is approximately $1 \times 10^{-4} / \mathrm{kyr}$, assuming that the T2 was formed in 10-11 kyr. This is much more rapid than that of the last inter-glacial marine terraces in the Muroto peninsula of Shikoku, Japan, with a tilting rate of $4 \times 10^{-5}$ / kyr, which formed by steep northward tilting against the Nankai subduction zone. The author suggests that this phenomenon is not related to mega-thrusting along the subduction zone, but rather to local deformation, probably caused by the reverse faulting of nearby active submarine faults along the west side of the islands.
\end{abstract}

Keywords: Submarine terrace, Active fault, Tectonic landform, Digital elevation model, Iheya-Izena islands, Nanseishoto Islands

${ }^{*}$ Correspondence: hgoto@hiroshima-u.ac.jp

Department of Geography, Graduate School of Humanities and Social Sciences, Hiroshima University, Kagamiyama 1-2-3, Higashi-hiroshima, Hiroshima, Japan

\begin{abstract}
Introduction
Late Quaternary tectonic deformation of coastal areas is usually examined using height distribution of paleoshorelines observed on marine terraces (Ota 1968; Nakata 1970). For example, in the outer zone of Southeast Japan along the Nankai trough, the northward
\end{abstract}


tilting of paleo-shore lines on Pleistocene and Holocene terraces has been reported, and relationships between coseismic deformation caused by mega-thrusting along the trough and inter-seismic deformation have been discussed (Yoshikawa et al. 1964; Maemoku 1988). However, it remains difficult to examine deformation along the subduction zone, where small, isolated islands, such as the Nanseishoto Islands, are distributed.

Shallow-sea features, such as cliffs and terraces, can provide essential information regarding topographical evolution and crustal movement, since the development of submarine topography above $-120 \mathrm{~m}$ has become relevant for sea-level changes during the last glacial period, including the Last Glacial Maximum (Zecchin et al. 2015; Martinez-Martos et al. 2016; Casalbore et al. 2017; Yokoyama et al. 2018). Since the 2000s, digital elevation models (DEM) surveyed by multi-beam sound systems have been acquired, and tectonic geomorphological studies in coastal areas have substantially progressed (Matsumoto et al. 2009; Arai et al. 2016). Active onshore faults in the outer zone of Southeast Japan were revealed to extend to the northwestward seafloor according to interpretation of coastal topographical maps and images of the Kikukawa fault (Ito and Izumi 2009; Sugiyama et al. 2010), the Nishiyama fault (Sato and Ito 2011), and the Tsujimiya fault on Yoronjima Island (Goto et al. 2018). Using examples from Santa Catalina Island near the San Andreas fault, Schumann et al. (2012) showed that the submerged terraces at depths greater than approximately -90 to $-120 \mathrm{~m}$ can indicate crustal deformation.

Herein, the author focuses on the widespread shallow submarine terraces around the Iheya-Izena islands, which exhibit indistinct marine terraces in the middle part of the Nanseishoto Islands. The author examined height differences between paleo-shore lines and displacements of the submarine terrace based on coastal topography showing the seafloor DEM surveyed by multi-beam systems together with an onshore digital surface model (DSM) produced using aerial photography. The author demonstrates that the shallow seafloor topography surrounding these isolated, small islands preserves useful information for understanding tectonic deformation.

\section{Tectonic setting}

The Nanseishoto Islands are distributed in an arc-shape on the island shelf of the Ryukyu arc, which formed during the subduction of the Philippine Sea plate beneath the Eurasia plate along the Nanseishoto trench (Fig. 1). The Okinawa trough, parallel to the Nanseishoto Islands, is a back-arc basin developed as a result of continental lithospheric extension behind the Nanseishoto trench since the Middle-to-Late Miocene (Sibuet et al. 1987). EW to
ENE trending grabens associated with rifting extend within the southwestern-middle region of the trough (Research Group for Active Faults in Japan 1991). Several active volcanos are aligned along the trough throughout the middle and northern regions (Geological Survey of Japan 2013).

In the middle part of the Nanseishoto Islands, the islands of Tokunoshima, Okinoerabu-jima, and Yoronjima are distributed on the island shelf, between the Amami-Oshima and Okinawa islands (Fig. 1B). The Iheya-Izena islands, including Iheyajima, Gushikawajima, Izenajima, and Yanahajima extend approximately $30 \mathrm{~km}$ northeast of Okinawajima and Yoronjima islands. Well-developed coral reefs occur along the Iheya-Izena islands, as well as on the island shelf. However, the islands of the island shelf, such as the Yoronjima and Okinoerabu-jima islands, were deposited on top of the coral marine terraces, whereas indistinct, low, small marine terraces occur on the Iheya-Izena islands. Furthermore, approximately $50 \mathrm{~km}$ off the northwest coast of the Iheya-Izena islands, ENE trending active normal faults and thermal springs related to rifting have been observed at the seafloor (Research Group for Active Faults in Japan 1991). These features suggest that the Iheya-Izena islands are located in the intermediate zone between the island shelf and the rift zone of the middle part of the Nanseishoto Islands.

Active tectonics between the Nanseishoto trench and Okinawa trough have received limited attention because the isolated islands in this region are widely distributed, and geodetic stations on these islands are located at irregular intervals. While the plate model between the Eurasian and Philippine sea plates along the Ryukyu arc estimated a high subduction rate $(60-80 \mathrm{~mm} /$ year $)$ (Miyazaki and Heki 2001), the coupling of the plate boundary is extremely weak (Sagiya 2004) or with less than 10\% (Watanabe and Tabei 2004) and tensional strain is dominant with perpendicular axis to the trench in the vicinity of Okinawa Island (Nakamura and Kawashima 2000). Moreover, the seafloor crustal deformation to the southeast off the Okinawa Island was recognized only in a limited zone near the trench axis at slab depth ranging from $13 \mathrm{~km}$ up to the seafloor based on the GNSS observation (Tadokoro et al. 2018).

Previous studies of active faulting during the Late Pleistocene have noted several small active fault strands cutting marine terraces on the island shelves of the islands of Tokunoshima, Okinoerabu-jima, and Yoronjima (Research Group for Active Faults in Japan 1991); however, there are as yet no reports of active faulting around the Iheyajima and Izenajima islands. This may be because certain areas of the islands and terraces have limited exposure, and there is a lack of detailed topographic data. 


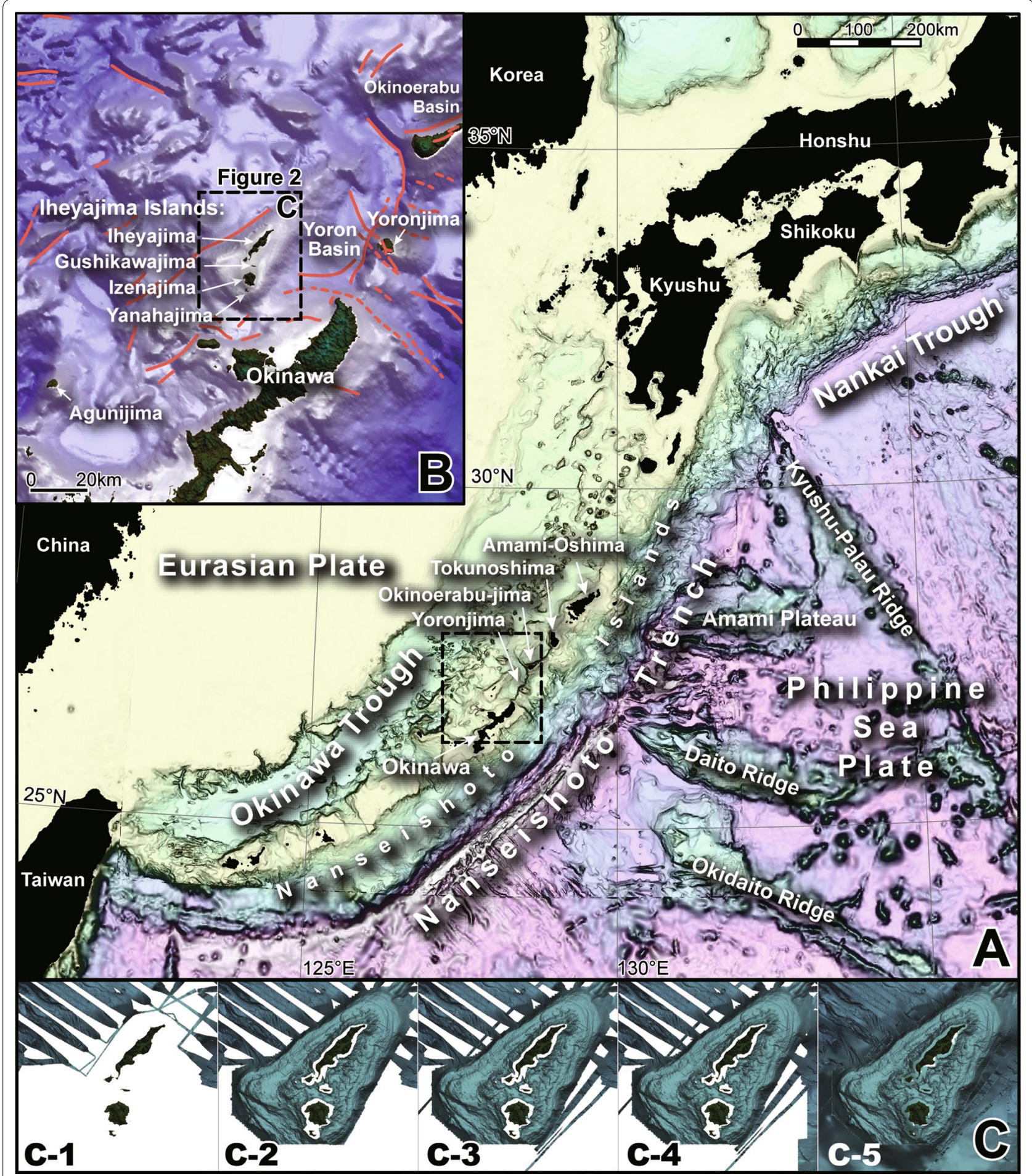

Fig. 1 Index map of the study area (A, B) and using data from this study (c). Shaded relief maps overlain by contour maps $(\mathbf{A}$ and $\mathbf{B})$ use a $500 \mathrm{~m}$ mesh DEM (J-EGG500) from the Japanese Coast Guard (JCG), a 1-degree mesh DEM (ETOPO 1) provided by the National Center for Environmental Information (USA), and inland SRTM-3 data provided by the US Geological Survey (USGS). Red lines in B indicate active fault lines identified by the Research Group for Active Faults in Japan (1991), Arai et al. (2015), Goto et al. (2018), and Honza et al. (1977). C-1: 0.65-s-mesh DEM of Sato et al. (2013) and onshore SRTM-3 data provided by the USGS, C-2: 1.44-s-mesh DEM of Yasuhara (2013) and C-1, C-3: 2.03-s-mesh DEM data from the Darwin website of the Japan Agency for Marine-Earth Science and Technology (JAMSTEC) and C-2, C-4: 2.08-s-mesh DEM produced from the contour lines on the chart of the Japan Hydrographic Association and C-3, C-5: 9.69-s-mesh DEM of the J-EGG500 from JCG and C-4 
The Yoron basin to the east of the Iheya-Izena islands is thought to be a half-graben, leading to the hypothesis that cliffs were taller than $500 \mathrm{~m}$ on the eastern side of the Yoron basin were normal fault scarps (Arai et al. 2018). On the other hand, Pleistocene marine terraces and seafloor to the north of Yoronjima Island exhibit anticlinal deformation with an axis extending parallel to the general trend of the island shelf (Goto et al. 2018); this suggests a need for the re-examination of active tectonics based on the tectonic geomorphology of the onshore and seafloor regions.

No study has been conducted for the Late Pleistocene deformation of Iheyajima Island, although normal faults are estimated to extend along the cliff off the west coast of Iheyajima Island (Arai et al. 2015). It is challenging to observe deformation around Iheyajima Island because this NE-trending narrow island has a maximum width of only $3 \mathrm{~km}$. Therefore, the author focuses on analyzing the widespread submarine terraces around the Iheya-Izena islands as a tool to examine crustal deformation in the intermediate zone between the island shelf and the rift zone.

\section{Method and materials}

\section{Collecting and processing seafloor DEM}

The author collected data for the seafloor DEM from several organizations and researchers. The Japan Coast Guard (JCG) conducted a multi-beam survey (MBS) along the shallow seafloor off the northwestern coast of Okinawa Island from 2008 to 2012 (Yasuhara 2013) (Fig. 1C). The National Institute of AIST also obtained the DEM of the deep seafloor by MBS around the middle part of the Nanseishoto Islands in 2012 (Sato et al. 2013). Using these data from JCG and AIST, the author generated 1.44-s-mesh (approximately $44 \mathrm{~m}$ ) data of seafloor DEMs from the JCG dataset and 0.65-s-mesh (approximately $20 \mathrm{~m}$ ) from the AIST dataset.

JAMSTEC (2020) stored and disseminated information regarding rock and sediment core samples, as well as the results of the MBS on their website, "Data and Sample Research System for Whole Cruise Information in JAMSTEC (Darwin)". The author retrieved these data from the JAMSTEC website and generated 2.03-s-mesh (approximately $63 \mathrm{~m}$ ) data of seafloor DEM.

The author reprocessed the 2.08-s-mesh (approximately $64 \mathrm{~m}$ ) DEM using digital bathymetric charts
(M7020) with 1-2 m interval counters proposed by the Japan Hydrographic Association (JHA) following the methods of Goto (2013) and combined these DEMs with the 9.69-s-mesh (approximately 300 m) DEM (J-EGG500) published by the JCG. DEMs were overlapped according to their decreasing resolutions (Fig. 1C).

\section{Producing topographical anaglyph}

The author imported seafloor DEMs and the 30-m-mesh ALOS DSM into Simple DEM Viewer ${ }^{\circledR}$ in order to produce topographic anaglyph images (Fig. 2A). When topographic anaglyph images are viewed using red-cyan glasses, topographic relief features can be easily identified (Goto 2016). Anaglyphs produced using DEM data are effective tools from which to identify tectonic geomorphic features, such as small fault scarps, broad ground deformation, and tilting surfaces over extensive areas (Goto 2018; Goto et al. 2017). In this study, the author produced an anaglyph map overlapped onto the black and white slope shading base map as well as contour lines indicating water depth.

\section{Producing the onshore DSM}

The author identified several strands of fault scarps in Izenajima Island by the interpretation of vintage aerial photographs. However, topography in the island was significantly changed after the 1980s. The previous topographies, e.g., terraces and small scarps, are not visible on the map using the 10-m mesh DEM of the Geospatial Information Authority of Japan (GSI), which is the highest resolution publicly available data created from the contours of the present topography.

The software used adopted SfM (Structure from Motion)-MVS (Multi-View Stereo) technology, such as Agisoft PhotoScan ${ }^{\circledR}$, enabling the creation of topographical models using aerial photographs and geographical coordinates as ground control points (GCPs). The topographies of partially destroyed, large, square, flat cultivated fields throughout Iheyajima Island are visible in the oldest existing large-scale color photographs, aerial photographs taken during the 1970s. Thus, the author adapted vintage colored GSI (COK-77-1) photographs taken in 1977 at a scale of approximately 1:10,000, and longitude and latitude information from points on the ground matched with a topographical map at a scale of 1:10,000 (Geographical Survey Institute of Japan); this

(See figure on next page.)

Fig. 2 Topography in and around the Iheya-Izena islands. A Topographic anaglyph with contour lines. Black contour lines on anaglyph indicate $-50 \mathrm{~m},-80 \mathrm{~m}$ and $-120 \mathrm{~m}$, respectively. B Distribution of submarine terraces and active faults. Arrows and red dashed lines indicate active fault scarps and the base of convex slopes deformed according to the basin surface, respectively. Black dashed lines show the locations of the topographical profiles shown in Figs. 4a and 5a. WSIS: west slope of Iheya-Izena islands named in this paper 


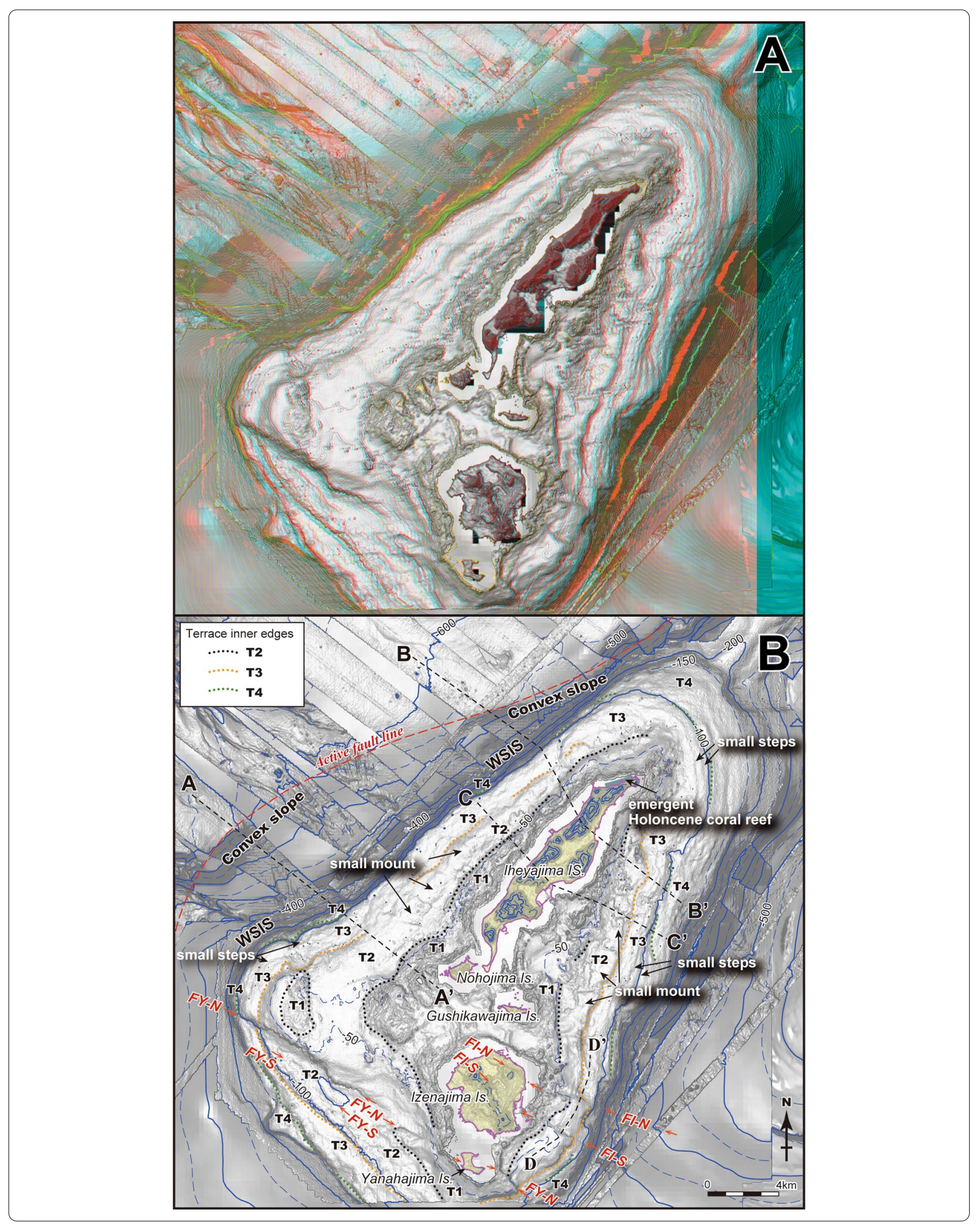


information was processed using PhotoScan Professional Edition ${ }^{\circledR}$ version 1.2.6, following the methods of Goto (2015) and Goto et al. (2018). This enabled us to generate a 0.12-s-mesh (approximately $3 \mathrm{~m}$ ) onshore DSM (Fig. 3). To evaluate the precision of the constructed map, the author obtained the present longitude and latitude information at unalterable points such as undestroyed agricultural land edges and street intersections, using GNSS (Spectra Precision Promark 120) in the field. This device can obtain the position with an error of $5 \mathrm{~mm}$ in horizontal and $10 \mathrm{~mm}$ vertical by referring the electronic reference point of GSI.

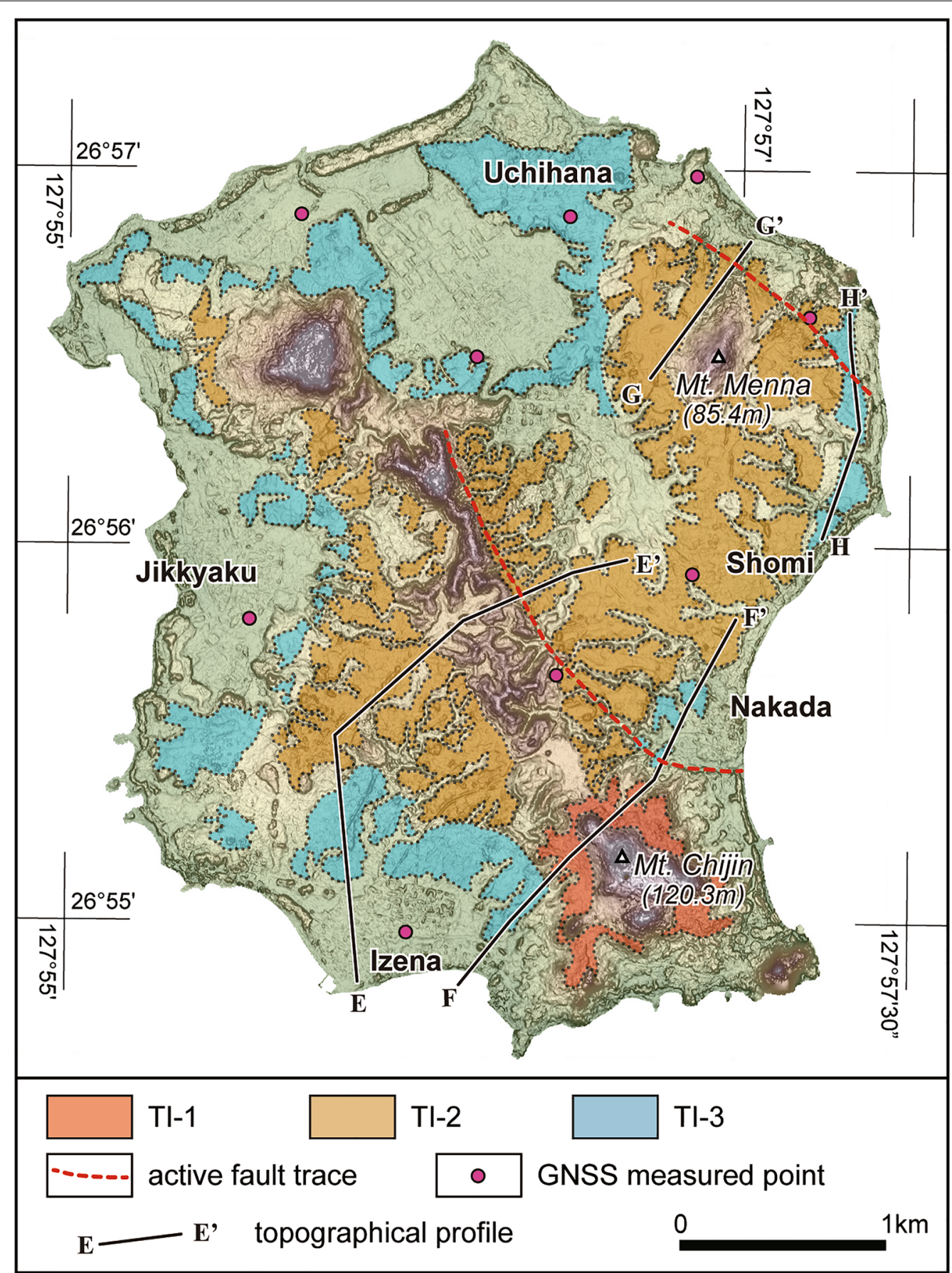

Fig. 3 Distribution of marine terraces and active faults in Izenajima Island. The topographical map is based on the DSM processed from aerial photographs taken in 1974 
The GCP residual three-dimensional error was approximately $0.26 \mathrm{~m}$. Validation using nine points demonstrated that this DSM exhibits a maximum root mean squared error (RMSE) of $0.67 \mathrm{~m}$. The author observed no inclination or distortion in the model itself. This DSM is thus sufficiently accurate to classify the marine terraces and to measure the height of fault scarp.

\section{Results}

\section{Classification of submarine terraces}

Around Iheya-Izena islands, the shallow seafloor above $-200 \mathrm{~m}$ is parallel to the NW-trending islands approximately $10 \mathrm{~km}$ to the north and $20 \mathrm{~km}$ to the south (Fig. 2). Several terrace-like features divided by small steps are found on the shallow seafloor. The surface of the shallow seafloor may be divided into four terraces by means of the interpretation of the stereoscopic anaglyph image; these terraces are named $\mathrm{T} 1, \mathrm{~T} 2, \mathrm{~T} 3$, and $\mathrm{T} 4$, in descending order (Figs. 2B and 4).

The surface of T2 distributed at depths between $-50 \mathrm{~m}$ and $-80 \mathrm{~m}$ is the most prominent, with a maximum width of approximately $3 \mathrm{~km}$; it surrounds the IheyaIzena islands, with the exception of the northeastern part. The surface of $\mathrm{T} 2$ is bounded on T3 by a continuous steep slope with a height of $<10 \mathrm{~m}$. The surface of T2 is relatively flat compared with modern coral reefs; however, it is characterized by topographic features, including small mounts distributed along the outer margin of the surface and a shallow depression along its inner edge. The upper heights of $\mathrm{T} 2$ at the west and east of Iheyajima Island are $-60 \mathrm{~m}$ and $-70 \mathrm{~m}$, respectively (Fig. 4).

The T1 terrace is bounded on its inner edge by the indented foot of modern coral reefs at depths of approximately $-20 \mathrm{~m}$. The outer margin of T1 extends intermittently around the islands. The top of this terrace reaches up to approximately $-30 \mathrm{~m}$ in depth and has an uneven surface. Thus, the distribution of $\mathrm{T} 1$ is challenging to identify. A slightly higher area among the uneven surfaces was observed along the outer margin of T1, as is typically observed at the western side of the islands. This topographical feature is similar to that seen in both T2 and the modern coral reef, suggesting that both reflect submarine coral reefs, as mentioned in preliminary reports (Yasuhara 2013).

T3 is distributed at depths between $-70 \mathrm{~m}$ and $-90 \mathrm{~m}$, and is gently inclined toward the deep sea. It is bounded by approximately 10 -m-high scarps to the east and west. Its surface is generally flat, with a few small steps such that its surface features are different from those of $\mathrm{T} 1$ and T2; this suggests that T3 is an erosional surface, not a submarine coral reef. The inner edges of this terrace are observed at depths of approximately $-70 \mathrm{~m}$ in the shallow western area and $-80 \mathrm{~m}$ in the east, respectively.
$\mathrm{T} 4$ is distributed below $-100 \mathrm{~m}$ and is clearly observed to the east of Iheyajima Island. Its surface has a width of less than $1 \mathrm{~km}$ and is gently inclined to the east. Small fragments of terraces below $-100 \mathrm{~m}$ remain to the west and southwest, and a well-defined step between T3 and $\mathrm{T} 4$ has not been recognized in the northeast, i.e., these remnants cannot be correlated to $\mathrm{T} 4$.

\section{Active fault scarp on the submarine terraces and on the island of Iheyajima Island}

Several active fault scarps displacing submarine terraces and onshore marine terraces are observed around Izenajima and Yanahajima islands on the anaglyph map produced in this study (Fig. 2). These NW-trending scarps are divided into two groups, named for the Izena fault zone and the Yanaha fault zone, respectively.

The Izena fault zone is composed of two strands, termed FI-N for the north and FI-S for the south (Fig. 2B). These extend from Izenajima Island to the T1, $\mathrm{T} 2$, and T3 submarine terraces and into the Yoron basin. Northward-facing scarps are distributed with southward convex shapes in map view. Distinct fault scarps appear on terrace $\mathrm{T} 2$ with a height of approximately $15 \mathrm{~m}$, along the foot of which small narrow depressions are identified (Fig. 5a). Such topographic features are commonly observed along normal faults.

Three steps of marine terraces are identified on Izenajima Island according to the interpretation of topographic anaglyph from the detailed DSM; these are named for TI-1, TI-2, and TI-3, in descending order (Figs. 3 and $5 \mathrm{~b})$. Rounded or sub-rounded gravel beds with a thickness of $5 \mathrm{~m}$ or less were observed beneath these terrace surfaces (Ujiie 2000), suggesting that they represent erosional marine surfaces. Fault scarps of FI-N, of approximately $10 \mathrm{~m}$ height, are present on TI- 2 and TI- 3 terraces (Fig. 5c). The fault scarps of FI-S extending along the northeastern side of the NW-trending central mountain with a height of $15 \mathrm{~m}$ on TI-2 are not distinct from submarine fault scarps on terrace T2 (Fig. $5 \mathrm{a}$ and b). The fault scarp heights on land are almost the same as that on the seafloor, so it may be suggested that these faults have started to move in recent geological time.

The Yanaha fault zone, with a length of $20 \mathrm{~km}$, is composed of two strands, named FY-N and FY-S (Fig. 2B). FY-N scarps, which face southward, are parallel to FY-S scarps facing northward, forming the narrow shallow graben in the middle part of the Yanaha fault zone. FY-N scarps are approximately $30 \mathrm{~m}$ high on terraces T2 and $\mathrm{T} 3$, and are not linear, but rather indented. The FY-S scarp on terrace T2 has a height of $<10 \mathrm{~m}$, and is also indented. The inner terrace edge of $\mathrm{T} 3$ does not have a lateral offset along this fault, suggesting that the Yanaha fault zone is characterized by normal faulting. 


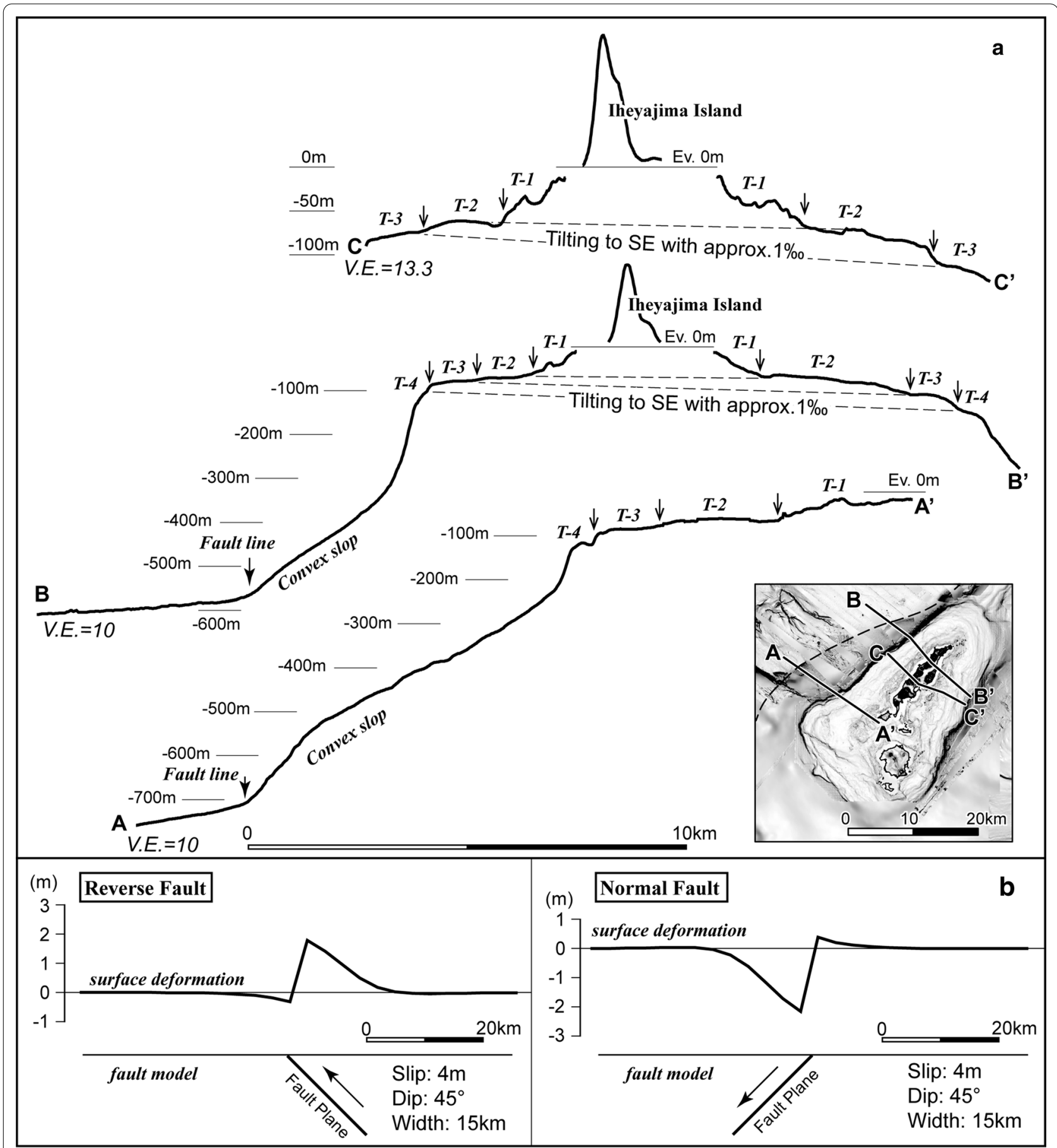

Fig. 4 Topographic profiles across the submarine terraces (a) and calculated vertical surface deformation (b). a Profile based on the DEM shown in Fig. 1C. The locations of the profiles used are shown in the lower right map and Fig. 2B. Downward open arrows indicate the boundaries of submarine terraces. $\mathbf{b}$ Vertical surface deformation across normal and reverse faults calculated by MICAP-G (Naito and Yoshikawa 1999), based on Okada (1992)

The Yahanajima Island, an uninhabited island, displayed L-shape in map view and formed by an uplifted coral reef (Ujiie 2000). The linear structure may be observed from the modern coral reef to the furthest extension of the northern foot of the WNW trending tableland in the south of the Yanahajima Island in 


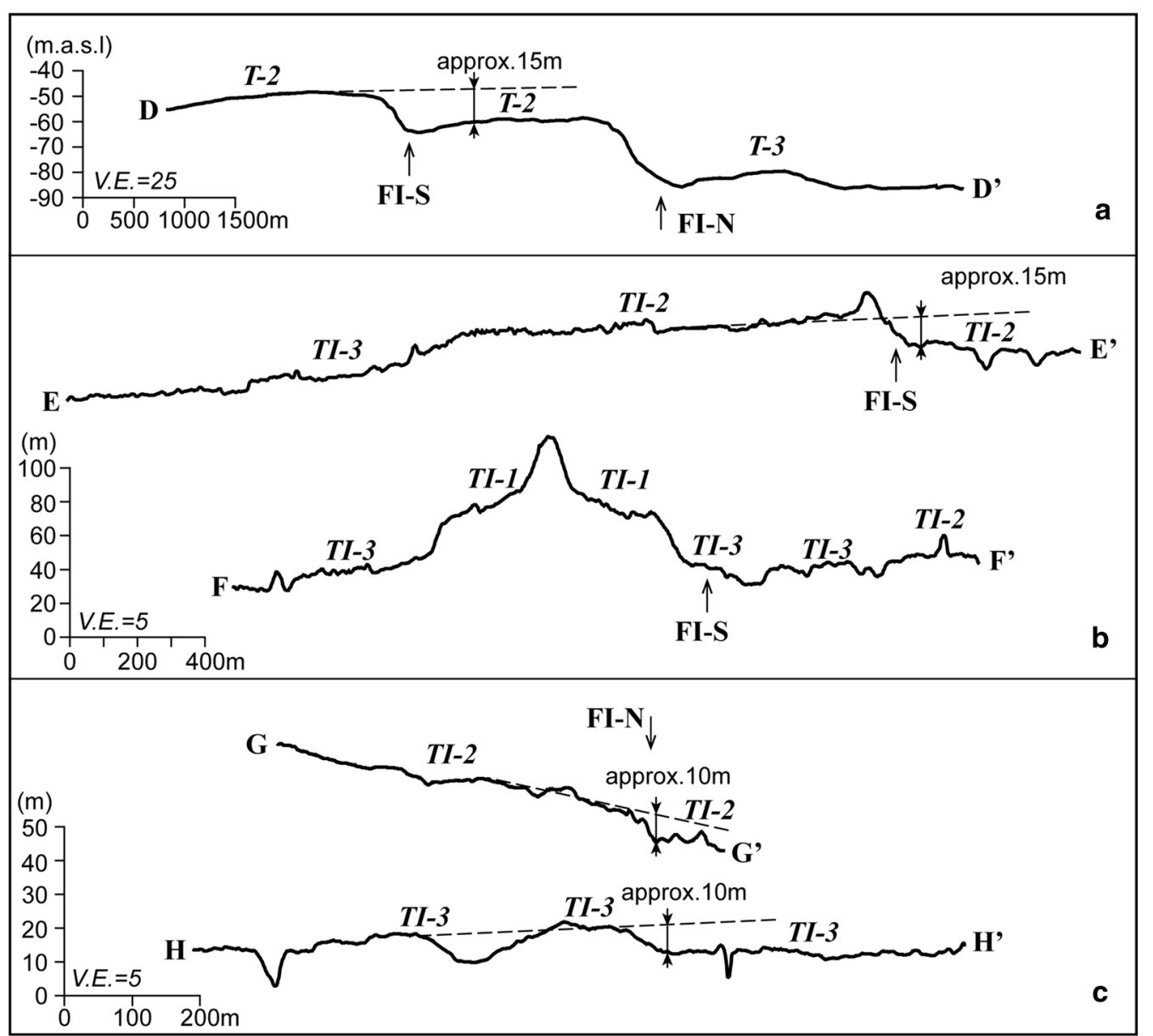

Fig. 5 Topographic profiles across the Izenajima fault zone. a Profile based on the DEM shown in Fig. 1C. b, $\mathbf{c}$ Profile based on the onshore DSM processed in this study. The locations of these profiles are shown in Figs. 2 and 3

aerial photographs, suggesting that it is displaced by FY-S (Fig. 2).

\section{Depth distribution of Paleo-shoreline on the submarine terrace}

Paleo-shoreline depths were preserved in the topography of the submarine terraces during the last glacial period related to isostatic change (Yokoyama et al. 2018). Since both the T1 and T2 terraces were formed as a coral reef, the depth of the reef crest indicates the paleo-sea level at the time of terrace formation. The reef crest depth on T1, which is distributed over a limited area, does not significantly differ throughout its distribution.

On the other hand, the reef crest depth is $-60 \mathrm{~m}$ on the west side and $-70 \mathrm{~m}$ on the east side of Iheyajima Island (Figs. 2B and 4a), where distinct terrace surfaces are developed, indicating southeastward tilting. The shallow inner edges of T3 exist at a depth of $-70 \mathrm{~m}$ at the west and $-80 \mathrm{~m}$ at the east (Figs. $2 \mathrm{~B}$ and $4 \mathrm{a}$ ), with the exception of areas in which active faults are distributed. This also indicates southeastward tilting. The depth of the submarine terrace surfaces was displaced by these active faults, as mentioned above, for example, the inner edge of T3 was clearly offset vertically with a height of approximately $30 \mathrm{~m}$ along FY-N.

\section{Discussion and conclusion}

The paleo-shoreline of submarine terraces $\mathrm{T} 2$ and $\mathrm{T} 3$ reveal that the shallow area around the Iheya-Izena islands tilted southeastward. Although Late Pleistocene marine terraces are distributed throughout these islands (Koike and Machida 2001), the crustal deformation of the region has not previously been known, primarily because the islands are too small to detect such motions, and since they extend NE, i.e., perpendicular to the tilting direction.

The gentle seaward platforms in the Nanseishoto Islands have often been observed from the inner break (IB) to the outer break (OB) at depths of 50-55 m, and are estimated to have formed around 10-11 kyr before 
the present (Hori and Kayane 2000). These topographical features and timing are concordant with the submarine coral reef in the Great Barrier Reef that fringe the Australian continent (Webster et al. 2018). These platforms are correlated to $\mathrm{T} 2$ in the present study, based on their distributed depth and topographical features.

Using the measured paleo-shoreline measured in this study, the tilting ratio of $\mathrm{T} 2$ and $\mathrm{T} 3$ around Iheyajima Island is calculated to approximately $1 \%$ (Fig. $4 \mathrm{a}$ ). The tilting rate is determined to be approximately $1 \times 10^{-4} /$ kyr, assuming that T2 formed around 10-11 kyr before the present (Hori and Kayane 2000). This is considerably faster than the tilting rates of the last inter-glacial marine terraces in the Muroto peninsula, for which the corresponding rates are $4 \times 10^{-5} / \mathrm{kyr}$, and exhibit steep northward tilting trends against the Nankai subduction zone caused by the mega-thrust (Yoshikawa et al. 1964). The author suggests that this is not related to the mega-thrust along the subduction, but rather to local deformation, probably caused by the nearby active fault.

The active submarine faults extend along the west of the island shelf, up to $25 \mathrm{~km}$ away from the shallow area (Arai et al. 2018; Goto et al. 2018) (Fig. 1B). The movement of these faults cannot explain the observed southeastward tilting due to the long distances involved. The NE-trending steep slope named West Slope of Iheya-Izena islands (WSIS) reaches the northwest basin of the shallow area with a depth of $-400 \mathrm{~m}$ (Fig. 2), and is exposed along the western margin of the shallow area, which is estimated to have formed by normal faulting (Arai et al. 2015). However, such rapid tilting rates have not been reported on the foot wall side of the normal fault.

On the other hand, convex slopes (Figs. 2 and 4a) observed on the seafloor along the foot of the steep slope (WSIS) seem to deform following the depositional surfaces of the sea basin, and exist within $3 \mathrm{~km}$ of the steep slope in the north and within $7 \mathrm{~km}$ of that in the south. Such convex and steeply inclined depositional surfaces are often observed at the side of the reverse fault hanging wall along the foot of inland mountains (Kaneda et al. 2008). The rapid rate of tilting, with more than $10-\mathrm{km}$ long wavelengths, can potentially be explained if the reverse fault is extended along the convex slope. Emergent coral reefs with an elevation of $+0.8 \mathrm{~m}$ to $+0.9 \mathrm{~m}$ formed in approximately 5000-3500 years BP are continuously distributed only along the northwestern coast of Iheyajima Island for about $1.5 \mathrm{~km}$ (Fig. 2B) (Pirazzoli and Koba 1989; Kawana 2001), and are concordant with the distribution of the convex slope.

These deformations and the distribution and style of active faults, including the FY and FI fault zone, can possibly be explained if the horizontal compressive stress axis with the time scale of Late Quaternary is perpendicular to the shallow area studied oriented NWSE, suggesting a similar stress environment throughout the island shelf; however, geodetic studies (Tadokoro et al. 2018) and geophysical investigations (Arai et al. 2018) suggest that this area is under the tensional stress field related to the Okinawa Trough. Taken together, these results show that shallow seafloor topography can preserve valuable information for understanding tectonic deformation, especially in isolated, small islands.

\section{Abbreviations \\ AIST: National Institute of Advanced Industrial Science and Technology; DEM: Digital elevation model; DSM: Digital surface model; GSI: Geospatial Informa- tion Authority of Japan; JAMSTEC: Japan Agency for Marine-Earth Science and Technology; JCG: Japan Coast Guard; MBS: Multi-beam survey.}

\section{Acknowledgements}

The author is grateful to Japan Coast Guard (JCG) and National Institute of Advanced Industrial Science and Technology (AIST) for providing original topographic data of seafloor to my research. The author also thanks lan M. Watkinson and an anonymous reviewer whose comments and suggestions helped improve and clarify this manuscript.

\section{Authors' contributions}

Did all analysis, wrote manuscript and produced figures. The author read and approved the final manuscript.

\section{Funding}

This study was partly supported by MEXT KAKENHI Grant Numbers 19H01374 and $16 \mathrm{~K} 01221$.

\section{Availability of data and materials}

The datasets generated and analyzed during the current study are not publicly available due to the policy of the organization that obtained the datasets.

\section{Declaration}

\section{Competing interests}

The authors declare that they have no competing interests.

Received: 8 November 2020 Accepted: 6 March 2021

Published online: 19 March 2021

\section{References}

Arai K, Sato T, Inoue T (2015) Geological map of the vicinity of northern Okinawa-Jima island. Marine Geology Map Series 85. Geological Survey of Japan, AIST. (in Japanese with English abstract)

Arai K, Matsuda H, Sasaki K, Machiyama H, Yamaguchi T, Inoue T, Sato T, Takayanagi H, Iryu Y (2016) A newly discovered submerged reef on the Miyako-Sone platform, Ryukyu Island Arc, northwestern Pacific. Mar Geol 373:49-54. https://doi.org/10.1016/j.margeo.2016.01.007

Arai K, Inoue T, Sato T (2018) High-density surveys conducted to reveal active deformations of the upper forearc slope along the Ryukyu Trench, western Pacific, Japan. Prog Earth Planet Sci 5:45. https://doi.org/10.1186/ s40645-018-0199-0

Casalbore D, Falese F, Martorelli E, Romagnoli C, Chiocci FL (2017) Submarine depositional terraces in the Tyrrhenian Sea as a proxy for paleo-sea level reconstruction: problems and perspective. Quatern Int 439:169-180. https://doi.org/10.1016/j.quaint.2016.02.027

Geological Survey of Japan (2013) Volcanoes of Japan 1:2,000,000 map series no. 11, 3rd edn. Geological Survey of Japan (AIST), Tsukuba (in Japanese with English abstract)

Goto H (2013) Submarine anaglyph images around japan islands based on bathymetric charts: explanatory text and sheet maps. The Hiroshima 
University studies, Graduate School of Letters, Special Issue 73. https:// doi.org/10.15027/35603 (in Japanese with English abstract)

Goto H (2015) Mapping of fault geomorphology using "Structure from Motion-Multi-View Stereo" photogrammetry with old/Hi-view aerial photography. Act Fault Res 42:73-83. https://doi.org/10.11462/afr. 2015.42_73 (in Japanese with English abstract)

Goto H (2016) Extensive area map of topographic anaglyphs covering inland and seafloor from detailed digital elevation model for identifying broad tectonic deformation. In: Kamae K, ed. Earthquakes, Tsunamis and Nuclear Risks: Prediction and Assessment beyond the Fukushima Accident. Springer, Tokyo, pp 65-74. http://link.springer. com/chapter/10.1007\%2F978-4-431-55822-4_5

Goto H, Tsutsumi H, Toda S, Kumahara Y (2017) Geomorphic features of surface ruptures associated with the 2016 Kumamoto earthquake in and around the downtown of Kumamoto City, and implications on triggered slip along active faults. Earth Planets Space 69:26. https://doi. org/10.1186/s40623-017-0603-9

Goto H (2018) Late Quaternary slip rates and vectors on the Median Tectonic Line active fault zone in eastern Shikoku, southwest Japan. Quat Int 471:267-277. https://doi.org/10.1016/j.quaint.2017.12.013

Goto H, Arai K, Sato T (2018) Topographic anaglyphs from detailed digital elevation models covering inland and seafloor for the tectonic geomorphology studies in and around Yoron Island, Ryukyu Arc, Japan. Geosciences 8:363. https://doi.org/10.3390/geosciences8100363

Honza A, Sato T, Inoue T (1977) Geological Map Around Ryukyu Arc. Marine Geology Map Series 7. Geological Survey of Japan

Hori K, Kayanne H (2000) Submarine morphology of the island shelf off the middle and South Ryukyu islands, Southwest Japan. Geogr Rev Jpn Ser A (Chirigaku Hyoron) 73(161-181):161-181. https://doi.org/10.4157/ grj1984a.73.3_161 (in Japanese with English abstract)

Ito $\mathrm{H}$, Izumi K (2009) The tectonic reliefs discovered at the sea extension portion of the Kikukawa fault zone. Act Fault Res 31:27-31. https://doi. org/10.11462/afr.2009.31_27 (in Japanese with English abstract)

JAMSTEC (2020) Data and sample research system for whole cruise information in JAMSTEC (Darwin). http://www.godac.jamstec.go.jp/darwin/e. Accessed 18 Oct 2020

Kaneda H, Nakata T, Tsutsumi H, Kondo H, Sugito N, Awata Y, Akhtar SS, Majid A, Khattak W, Awan AA, Yeats RS, Hussain A, Ashraf M, Wesnousky SG, Kausar AB (2008) Surface rupture of the 2005 Kashmir, Pakistan, earthquake and its active tectonic implications. Bull Seismol Soc Am 98:521-557. https://doi.org/10.1785/0120070073

Kawana T (2001) Holocene tilting in the northern and central Ryukyu Islands, as deduced from expansion of the Okinawa Trough. J Geogr 110:433-438. https://doi.org/10.5026/jgeography.110.3_433 (in Japanese)

Koike K, Machida H (2001) Atlas of quaternary marine terraces in the Japanese Islands. p. 105, Maps (2 Sheets), CD-ROM (3 Disks). University of Tokyo Press, Tokyo (in Japanese with English abstract)

Maemoku H (1988) Holocene crustal movement in Muroto Peninsula Southwest Japan. Geogr Rev Jpn Ser A Chirigaku Hyoron 61:747-769. https://doi.org/10.4157/grj1984a.61.10_747 (in Japanese with English abstract)

Martinez-Martos M, Galindo-Zaldivar J, Lobo FJ, Pedrera A, Ruano P, LopezChicano M, Ortega-Sánchez M (2016) Buried marine-cut terraces and submerged marine-built terraces: the Carchuna-Calahonda coastal area (southeast Iberian Peninsula). Geomorphology 264:29-40. https:// doi.org/10.1016/j.geomorph.2016.04.010

Matsumoto T, Shinjo R, Nakamura M, Kimura M, Ono T (2009) Submarine active normal faults completely crossing the southwest Ryukyu Arc Tectonophysics 466:289-299. https://doi.org/10.1016/j.tecto.2007.11. 032

Miyazaki S, Heki K (2001) Crustal velocity field of southwest Japan: subduction and arc-arc collision. J Geophys Res 106:4305-4326. https://doi. org/10.1029/2000JB900312

Naito H, Yoshikawa S (1999) A program to assist crustal deformation analysis. Zisin J Seismol Soc Japan 52:101-103. https://doi.org/10.4294/zisin 1948.52.1_101 (in Japanese with English abstract)

Nakamura M, Kawashima A (2000) Horizontal movement of Nansei islands inferred from GPS data. Bull Fac Sci Univ Ryukyus 70:63-72. http://hdl. handle.net/20.500.12000/15367 (in Japanese with English abstract)
Nakata T (1970) The coastal terraces of the Tane-ga-shima island and the mode of its crustal movement. Geogr Rev Jpn 41:601-614. https://doi. org/10.4116/jaqua.30.175 (in Japanese with English abstract)

Okada Y (1992) Internal deformation due to shear and tensile faults in a half-space. Bull Seismol Soc Am 82:1018-1040

Ota Y (1968) Deformed shorelines and late quaternary crustral movements in Japan. Memoirs Geological Soc Jpn 2:15-24. https://doi.org/10. 4116/jaqua.30.175 (in Japanese with English abstract)

Pirazzoli PA, Koba M (1989) Late Holocene sea-level changes in Iheya and Noho Islands, the Ryukyus, Japan. Earth Sci [Chikyu Kagaku] 43:1-6. https://doi.org/10.15080/agcjchikyukagaku.43.1_1

Research Group for Active Faults in Japan (1991) Active faults in Japan: sheet maps and inventories. Tokyo Univ. Press, Tokyo (in Japanese with English abstract)

Sagiya T (2004) The continuous GPS observation in Japan and its impact on earthquake studies. Earth Planets Space. https://doi.org/10.1186/BF033 53077

Sato K, Ito K (2011) Preliminary report of bathymetric survey off Fukuoka Prefecture, Report of hydrographic and Oceanographic Researches 47:61-65. http://hdl.handle.net/1834/15685 (in Japanese with English abstract)

Sato T, Arai K, Matsumoto D (2013) Preliminary result of the GH12 seismic survey. In: Tukuba AraiK (ed) Marine geological and geophysical studies around Okinawa Islands_-around Okinoerabu-Jima Island-Preliminary Reports on Research in the 2012 Fiscal Year. GSJ Interim Report, No. 61. Geological Survey of Japan (AIST), pp 29-39 (in Japanese with English abstract)

Schumann RR, Minor SA, Muhs DR, Groves LT, McGeehin JP (2012) Tectonic influences on the preservation of marine terraces: old and new evidence from Santa Catalina Island, California. Geomorphology 179:208-224. https://doi.org/10.1016/j.geomorph.2012.08.012

Sibuet JC, Letouzey J, Barbier F, Charvet J, Foucher JP, Hilde TWC, Kimura M, Chiao LY, Marsset B, Muller C, Stéphan J (1987) Back arc extension in the Okinawa Trough. J Geophys Res 92:14041-14063. https://doi.org/ 10.1029/JB092iB13p14041

Sugiyama S, Horisako J, Fukuyama I, Tanaka K, Nishishita A, Narita M, Kato M, Ujihara N, Mori H, Inoue W, Honma F, Kyuma Y (2010) Bathymetric survey off the Japan Sea coast of Yamaguchi Prefecture [preliminary report]. Rep Hydrograph Oceanograph Res 46:92-95. http://hdl.handle. net/1834/15686 (in Japanese with English abstract)

Tadokoro K, Nakamura M, Ando M, Kimura H, Watanabe T, Matsuhiro K (2018) Interplate coupling state at the Nansei-Shoto (Ryukyu) trench, Japan, deduced from seafloor crustal deformation measurements. Geophys Res Lett 45:6869-6877. https://doi.org/10.1029/2018GL0786 55

Ujiie H (2000) Geology of the Iheya Jima and Izena Jima district. with geological sheet map at 1:50,000, Geological Survey of Japan, p 25. https:// www.gsj.jp/data/50KGM/PDF/GSJ_MAP_G050_18001_2001_D.pdf. (in Japanese with English abstract)

Watanabe T, Tabei T (2004) GPS velocity field and seismotectonics of the Ryukyu Arc, Southwest Japan. Zisin J Seismol Soc Japan. 57:1-10. https://doi.org/10.4294/zisin1948.57.1_1 (in Japanese with English abstract)

Webster JM, Braga JC, Humblet M, Potts DC, Iryu Y, Yokoyama Y, Fujita K, Bourillot R, Esat TM, Fallon S, Thompson WG, Thomas AL, Kan H, McGregor HV, Hinestrosa G, Obrochta SP, Lougheed BC (2018) Response of the Great Barrier Reef to sea-level and environmental changes over the past 30,000 years. Nature Geosci 11:426-432. https:// doi.org/10.1038/s41561-018-0127-3

Yasuhara T (2013) Preliminary report on the bathymetric surveys along the northwestern coast of Okinawa Island. Rep Hydrogr Oceanogr Res 50:80-83. https://www1 .kaiho.mlit.go.jp/GIJUTSUKOKUSAI/KENKYU/ report/rhr50/rhr50-tb02.pdf (in Japanese with English abstract)

Yokoyama Y, Esat TM, Thompson WG, Thomas AL, Webster JM, Miyairi Y, Sawada C, Aze T, Matsuzaki H, Okuno J, Fallon S, Braga J, Humblet M, Iryu Y, Potts DC, Fujita K, Suzuki A, Kan H (2018) Rapid glaciation and a two-step sea level plunge into the Last Glacial Maximum. Nature 559:603-607. https://doi.org/10.1038/s41586-018-0335-4

Yoshikawa T, Kaizuka S, Ota Y (1964) Mode of crustal movement in the late Quaternary on the southeast coast of Shikoku. Southwestern Japan. Geogr Rev Jpn Chirigaku Hyoron Geogr Rev of Japan 37:627-648. 
https://doi.org/10.4157/grj.37.627 (in Japanese with English abstract)

Zecchin M, Ceramicola S, Lodolo E, Casalbore D, Chiocci FL (2015) Episodic, rapid sea-level rises on the central Mediterranean shelves after the Last Glacial Maximum: a review. Mar Geol 369:212-223. https://doi.org/10. 1016/j.margeo.2015.09.002

\section{Publisher's Note}

Springer Nature remains neutral with regard to jurisdictional claims in published maps and institutional affiliations.
Submit your manuscript to a SpringerOpen ${ }^{0}$ journal and benefit from:

- Convenient online submission

- Rigorous peer review

- Open access: articles freely available online

- High visibility within the field

- Retaining the copyright to your article

Submit your next manuscript at $\boldsymbol{\nabla}$ springeropen.com 